\title{
Row Spacing, Landscape Position, and Maize Grain Yield
}

\author{
Gustavo Ángel Maddonni ${ }^{1,2}$ and Joaquín Martínez-Bercovich ${ }^{3}$ \\ ${ }^{1}$ Instituto de Investigaciones Fisiológicas y Ecológicas Vinculadas a la Agricultura (IFEVA), Avenue San Martín 4453, \\ C1417DSE Ciudad de Buenos Aires, Argentina \\ ${ }^{2}$ Cátedra de Cerealicultura, Departamento de Producción Vegetal, Facultad de Agronomía, Universidad de Buenos Aires, \\ Avenue San Martín 4453, C1417DSE Buenos Aires, Argentina \\ ${ }^{3}$ Dow AgroScience Argentina S.A., Ruta 8 km 264, Colón, 2720 Buenos Aires, Argentina
}

Correspondence should be addressed to Gustavo Ángel Maddonni; maddonni@agro.uba.ar

Received 25 June 2013; Accepted 8 October 2013; Published 14 January 2014

Academic Editor: Robert J. Kremer

Copyright ( 2014 G. Á. Maddonni and J. Martínez-Bercovich. This is an open access article distributed under the Creative Commons Attribution License, which permits unrestricted use, distribution, and reproduction in any medium, provided the original work is properly cited.

\begin{abstract}
The use of narrow row spacing for the different landscape positions of a field could punish maize (Zea mays L.) grain yield. Two experiments were conducted (2006/07 and 2007/08) at different landscape positions in the Inland Pampas of Argentina. Hybrid DK190MG was grown at the commonest plant density used at each landscape position (approximately $5.1 \mathrm{plants} / \mathrm{m}^{2}$ at the summit, 6.5 plants $/ \mathrm{m}^{2}$ at shoulder-slope position, and 7.6 plants $/ \mathrm{m}^{2}$ at foot-slope position) with three row spacings $(0.38 \mathrm{~m}, 0.52 \mathrm{~m}$, and $0.38 \mathrm{~m}$ in a $2 \times 1$ skip-row pattern). At the silking stage of maize crops, soil water content $(0-200 \mathrm{~cm}$ depth) and maximum light capture differed $(0.05<P<0.001)$ among landscape positions but were similar among row spacings. Differences in grain yield among landscape positions (mean 806, 893, and $1104 \mathrm{~g} / \mathrm{m}^{2}$ at the summit, shoulder-slope position, and foot-slope position, resp.) were related to kernel number $/ \mathrm{m}^{2}(r=0.94)$, which was closely related $(r=0.90)$ to light capture around silking. Grain yield reductions (6 to $20 \%$ ) were recorded when crops were cultivated in rows $0.38 \mathrm{~m}$ apart. The skip-row pattern did not improve grain yield. Maize grain yield was optimized in rows $0.52 \mathrm{~m}$ apart along the sandy landscape positions of the fields.
\end{abstract}

\section{Introduction}

Maize (Zea mays, L.) production in Argentina was traditionally concentrated within the most productive sub-region of the Pampas, that is, the Rolling Pampas [1]. This humid (approximately $950 \mathrm{~mm} /$ year) temperate (mean annual temperature of $16^{\circ} \mathrm{C}$, frost-free period of 240 days) area has the least number of climatic constraints to agriculture in Argentina and the most fertile soils (i.e., Typic Argiudolls; [2]) of the Southern Hemisphere [3]. Favorable international prices of agricultural commodities (http://www.fao.org/es/ esc/prices) together with changes in climate trends; for example, increases in precipitation up to $50 \%$ in some areas of the Pampas [4], have promoted the expansion of annual crops into previously semiarid areas (less than $700 \mathrm{~mm} /$ year, mean annual temperature of $16^{\circ} \mathrm{C}$ and a frost-free period of 220 days); for example, to the west and southwest of the Rolling Pampas, the Inland Pampas [1], where grazed pasture was the dominant land use. Soils of this subregion of the Pampas are predominantly Entic and Typic Hapludolls, with few constraints on root growth but with low water storage capacity (less than $100 \mathrm{~mm}$ in the first $1 \mathrm{~m}$ of the profile versus $170 \mathrm{~mm}$ of Typic Argiudolls) [5]. However, depth of groundwater in the sandy landscapes of this region varies from $<1 \mathrm{~m}$ (at foot-slope positions) to $>4 \mathrm{~m}$ (at the summit) over distances less than $2000 \mathrm{~m}$, modifying water balance of rainfed crops and accounting for within-field variations of crop yields [6].

Among annual grain crops, maize is the most sensitive one to groundwater depth variations [6]. Selection of the most appropriate crop management for each landscape position is necessary to optimize maize grain yield under these heterogeneous environments. Plant population density and interrow spacing are commonly reduced under more restrictive environments [7-13], but interactions between these cultural practices and environmental conditions on maize grain 
yield were reported $[14,15]$. An ecophysiological approach was necessary to understanding the underlying mechanisms of these interactions [16].

Maize grain yield is mainly determined by kernel number per unit land area $[17,18]$. This grain yield component is positively related to crop growth around silking [19]. Crop growth depends on the amount of photosynthetically active radiation intercepted by the canopy (IPAR) and the efficiency of conversion of IPAR into biomass; for example, radiation use efficiency (RUE) [20]. Thus, differences in maize kernel number per unit land area among hybrids, locations, plant densities, and interrow spacings have been related to daily IPAR or to maximum fraction of incident PAR intercepted (fIPAR) by crops $[9,21,22]$. Previous studies documented that row spacing reduction did not modify maize canopy size (i.e. leaf area index); but increased maximum fIPAR and grain yield at low plant densities ( 40-65.000 plants/ha) $[15,16]$ or at high plant densities (>75.000 plants/ha) but with low soil resources that affected canopy size $[9,10]$. Consequently, a positive impact of row spacing reduction on maize grain yield could be expected at the summit due to its rare supply of soil resources $[23,24]$ and the low plant densities used at this landscape position. Contrastingly, some evidences of RUE reductions in maize crops with large canopy size (i.e. crops at high plant densities growing in environments with few limitations) when cultivated in narrow rows exist [21]. Possibly, for crops of the nonsaline foot-slope positions cultivated at high plant densities, a skip-row pattern (i.e., a planting pattern where an entire row is not planted adjacent to planted rows [25]) or a moderate row spacing (e.g., $0.52 \mathrm{~m}$ ) could contribute to sustain RUE close to maximum value by a deepest light penetration within leaves strata $[15,26,27]$. Additionally, row spacing can also influence soil water utilization; water use of maize rainfed crops was greater in narrow $(0.38 \mathrm{~m})$ than in wide rows $(0.57$ and $0.76 \mathrm{~m})[10,28]$.

Farmers with current technology and previous information of intrafield variability [29] can easily vary maize plant density along the landscape positions of the fields. Contrarily, row spacing is not so simple to be modified. Hence, the use of the same row spacing for the different landscape positions of a field could punish maize grain yield. For testing this hypothesis, two experiments were conducted at fields with different landscape positions in the Inland Pampas of Argentina. Maize hybrid DK190MG, extensively cultivated in this region, was grown at the commonest plant density used at each landscape position (approximately $5.1 \mathrm{plants} / \mathrm{m}^{2}$ at the summit, 6.5 plants $/ \mathrm{m}^{2}$ at the shoulder-slope position, and 7.6 plants $/ \mathrm{m}^{2}$ at the foot-slope position) with three row spacings $(0.38 \mathrm{~m}$, $0.52 \mathrm{~m}$, and $0.38 \mathrm{~m}$ in a $2 \times 1$ skip-row pattern). The efects of row spacing and landscape position on the following variables were analyzed: (i) soil water content at two ontogenic stages (silking and physiological maturity), (ii) two descriptive traits of the activity of the canopy around silking (i.e. maximum fIPAR and leaf chlorophyll content), and (iii) total crop biomass, grain yield per unit land area, and grain yield components.

\section{Material and Methods}

2.1. Experimental Design and Growing Conditions. Field experiments were conducted in the Inland Pampas of Argentina during the growing season of 2006/2007 and 2007/ 08 at Vicuña Mackenna $\left(34^{\circ} 12 \mathrm{~S}, 64^{\circ} 18 \mathrm{~W}\right)$ and Vedia $\left(34^{\circ} 24 \mathrm{~S}\right.$, $\left.61^{\circ} 32 \mathrm{~W}\right)$, respectively. Experiments were conducted on the predominant soil types: Entic Haplustoll at Vicuña Mackenna (all landscape positions) and Entic Hapludoll (the summit and the shoulder-slope position) and Typic Hapludoll (footslope position) at Vedia. These soils are deep $(>200 \mathrm{~cm}$ soil depth) sandy to sandy-loam textured, well drained, with low to medium soil organic carbon content $(\sim 2 \mathrm{Mg} / \mathrm{ha}$ in the $0-20 \mathrm{~cm}$ soil depth) and low $(<50 \mathrm{~mm}$ in the $0-$ $100 \mathrm{~cm}$ soil depth) to medium $(\sim 100 \mathrm{~mm}$ in the $0-100 \mathrm{~cm}$ soil depth) water storage capacity. The experiments were sown on Oct 15, 2006, at Vicuña Mackenna (location $1 ; \mathrm{L}_{1}$ ) and on Nov 12, 2007, at Vedia (location 2; $\mathrm{L}_{2}$ ). The different date of sowing between Ls was related to the most suitable fallow period for soil water accumulation. From soybean (Glycine max; the common crop before maize) harvest (mid-April) to maize sowing date (early October and early November at $\mathrm{L}_{1}$ and $\mathrm{L}_{2}$, resp.) total rainfall is generally higher than soil water storage capacity. Hence, sowing of maize crops takes place when soil profiles are close to the upper limit of soil water holding capacity. The single-cross flint maize hybrid DK190MG (Dekalb-Monsanto Argentina S.A.) was mechanically cultivated. One field ( $150 \mathrm{ha})$ with all landscape positions was selected at each location. Plant population density was varied along the landscape (4.5 and 5.8 plants $/ \mathrm{m}^{2}$ at the summit at $\mathrm{L}_{1}$ and $\mathrm{L}_{2}$, resp.; 6.2 and 6.8 plants $/ \mathrm{m}^{2}$ at shoulder-slope position at $\mathrm{L}_{1}$ and $\mathrm{L}_{2}$, resp.; and 7.3 and 7.8 plants $/ \mathrm{m}^{2}$ at foot-slope position at $\mathrm{L}_{1}$ and $\mathrm{L}_{2}$, resp.). The different landscape position areas were previously defined by visual observation of the topography and maps of the within-field variation [6]. Within each landscape position (main factor), three row spacings $(0.38 \mathrm{~m}, 0.52 \mathrm{~m}$, and $0.38 \mathrm{~m}$ in a $2 \times 1$ skip-row pattern) were arranged in a completely randomized design with three replicates. Plots had 24 rows, $200 \mathrm{~m}$ long, and rows were cultivated slopewise with an east-west orientation. All experiments were conducted under rainfed conditions without nutrient application and kept free of weeds, insects, and diseases. Fertilization was not applied to test the different native nutrient supply among landscape positions.

Mean air temperature, solar radiation, and rainfalls were daily recorded at each $\mathrm{L}$ close to the experimental area. Meteorological conditions differed between years. Both growing seasons were characterized by intermediate air temperatures (ca. $21.3^{\circ} \mathrm{C}$ ) and the higher daily irradiance values (ca. 22.5 $\mathrm{MJ} / \mathrm{m}^{2} \mathrm{~d}$ ) registered during the last 30 years. Contrarily, total rainfalls during maize cycles were above climatic records at $\mathrm{L}_{1}$ (577 versus $512 \mathrm{~mm}$ ) and below them at $\mathrm{L}_{2}$ (343 versus $531 \mathrm{~mm}$ ). Similarly, total rainfalls during the 30 -day period around silking and during the postsilking period were above the records at $\mathrm{L}_{1}$ (123 versus $107 \mathrm{~mm}$ and 206 versus $167 \mathrm{~mm}$ for the period around silking and the postsilking period, 
resp.) and below them at $\mathrm{L}_{2}$ (83 versus $130 \mathrm{~mm}$ and 107 versus $390 \mathrm{~mm}$ for the period around silking and the postsilking period, resp.).

2.2. Measurements. A representative area (i.e., with homogeneous topography and the target plant population density) of each plot was selected and five successive plants were tagged in two adjacent rows (i.e., ten plants/plot). These plants were used to estimate maximum fIPAR and leaf chlorophyll content close to silking $\left(\mathrm{R}_{1-2}[30]\right)$ and total crop biomass and grain yield and grain yield components at physiological maturity $\left(\mathrm{R}_{6}[30]\right)$. Measurements of soil water content were performed adjacently to these plants at $R_{1-2}$ and $R_{6}$.

Maximum fIPAR was calculated from PAR measurements obtained above the canopies and incident PAR registered between the green and the senesced leaves strata. Measurements were made with a line quantum-sensor of $1 \mathrm{~m}$ long (Bar-Rad, Cavadevices.com, Buenos Aires, Argentina). Five independent records were taken within each plot, between 1100 and $1400 \mathrm{~h}$ on a clear day. For crops in rows $0.38 \mathrm{~m}$ and $0.52 \mathrm{~m}$ apart, the sensor bar was centered in one row of tagged plants and placed diagonally across the row with the extremes of the bar at the mid distance of the interrow spacing (i.e., at $0.19 \mathrm{~m}$ and $0.26 \mathrm{~m}$ of the rows for the $0.38 \mathrm{~m}$ and $0.52 \mathrm{~m}$ row spacing, resp.) [31]. For crops in the skip-row pattern, the sensor bar was centered at the mid distance $(0.19 \mathrm{~m})$ of the interrow spacing of the two adjacent rows and also placed diagonally across the rows, with the extremes of the bar at the middistance (at $0.38 \mathrm{~m}$ of the rows) of the largest interrow spacing $(0.76 \mathrm{~m})$.

Leaf chlorophyll content, used as an indicator of leaf $\mathrm{N}$ status [32], was estimated with a Minolta SPAD-502 chlorophyll meter. This plant trait is related to specific leaf nitrogen (SLN), and maize RUE declines with SLN $<1.2 \mathrm{~g} \mathrm{~N} / \mathrm{m}^{2}$ [33]. All tagged plants were read (three readings/leaf) on the leaf subtending the topmost ear [34]. A model was obtained to estimate SLN (in $\mathrm{gN} / \mathrm{m}^{2}$ of green leaf area) from SPAD readings [32]. For this purpose, 10 leaves were randomly sampled at each landscape position of both Ls and leaf areas were immediately estimated by allometry [35]. Samples were dried at $60^{\circ} \mathrm{C}$ and weighted and leaf $\mathrm{N}$ content was determined by micro-Kjeldahl method [36].

Soil water content (in $\mathrm{mm}$ ) was gravimetrically estimated from $0-200-\mathrm{cm}$ depth at $20 \mathrm{~cm}$ intervals. Soil samples were taken with a core ( $35 \mathrm{~mm}$ diameter) at the mid distance of the interrow spacing of tagged plants of both $0.38 \mathrm{~m}$ and $0.52 \mathrm{~m}$ row spacing and at the mid distance of the largest interrow spacing of the skip-row pattern. Samples were identified and immediately placed within plastic bags to prevent desiccation. Soil samples were weighted (in g) before and after being oven-dried at $100^{\circ} \mathrm{C}$ until total desiccation and water content of each soil layer was calculated as follows:

Soil water content (in $\mathrm{mm}$ )

$$
=\frac{[(\text { water mass } / \text { soil dry mass }) * 100 *(\text { soil bulk density/water bulk density }) * \text { layer depth }(\text { in } \mathrm{cm})]}{10} .
$$

Soil bulk density (in $\mathrm{g} / \mathrm{cm}^{3}$ ) of each soil layer had been previously determined.

At $\mathrm{R}_{6}$, tagged plants were harvested and dried at $80^{\circ} \mathrm{C}$ until constant weight. Total biomass and grain yield were weighted and harvest index was estimated as the quotient between grain yield and total plant biomass. Prolificacy (i.e. ears plant ${ }^{-1}$ ) and kernel number were counted, and kernel weight was calculated as the quotient between grain yield, and kernel number. Total biomass, grain yield and kernel number were expressed per unit land area affecting mean values of these traits by the corresponding plant density at each landscape position. The estimated yields obtained by sampling correlate well with the mechanically harvested grain yields (data not showed).

2.3. Statistical Analyses. Treatment effects on measured variables were evaluated by ANOVA. The ANOVA was performed considering the landscape position as the main factor and row spacing as the subfactor. Location effect was analyzed considering the landscape positions as replicates. Comparison of the means was performed with the least square deviation test. A hyperbolic function was fitted to the relationship between SPAD readings and SLN as follows:

$$
\begin{array}{r}
\mathrm{SPAD}=\frac{(96.5 *(\mathrm{SLN}-0.34))}{(1+1 *(\mathrm{SLN}-0.34))}, \quad \text { for } \mathrm{SLN}>0.34 \\
\left(R^{2}=0.78, n=60\right) .
\end{array}
$$

The fitting of the model was performed by using the user-defined functions routine of Table Curve V 3.0 [37]. Correlation analyses among variables were performed for the whole data set (i.e. combining locations, landscape positions, and row spacings) and linear regressions were fitted among some variables.

\section{Results}

In $\mathrm{L}_{1}$, soil water content $(0-20 \mathrm{~cm})$ at $\mathrm{R}_{1}$ and $\mathrm{R}_{6}$ of maize crops differed $(P<0.001)$ among landscape positions (Table 1). The larger mean values were recorded at the footslope position ( $\sim 50$ and $477 \mathrm{~mm}$ at $R_{1}$ and $R_{6}$, resp.) and the lower ones at the summit $\left(\sim 172\right.$ and $226 \mathrm{~mm}$ at $R_{1}$ and 


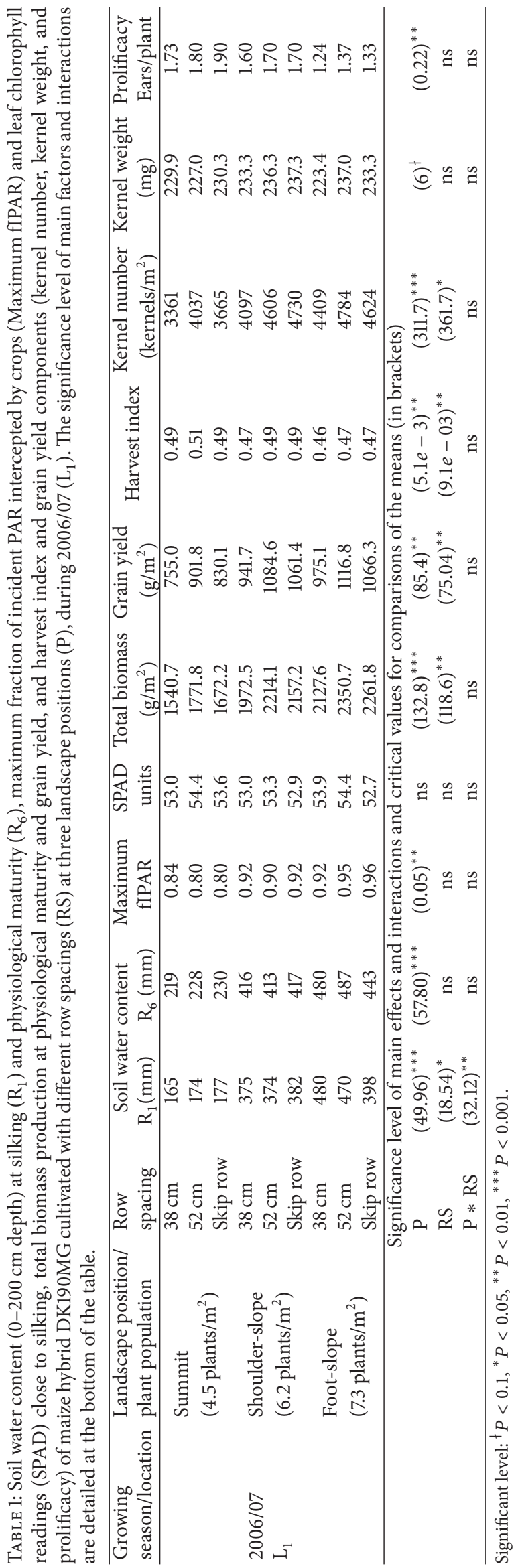


$\mathrm{R}_{6}$, resp.). Mean values of soil water content at shoulderslope position ( 377 and $416 \mathrm{~mm}$ at $\mathrm{R}_{1}$ and $\mathrm{R}_{6}$, resp.) were lower than those recorded at the foot-slope position but greater than those recorded at the summit. Only at $R_{1}$, maize cultivated at the foot-slope position with the skip-row pattern exhibited a slightly lower soil water content $(P<$ 0.01 for landscape position $\mathrm{x}$ row spacing interaction) than those in narrow rows (i.e. 0.38 and $0.52 \mathrm{~m}$ apart). Mentioned differences among row spacings were mainly promoted by water contents of the deeper $(>140 \mathrm{~cm})$ soil layers (Figure 1).

In $\mathrm{L}_{2}$ soil water contents $\left(0-200 \mathrm{~cm}\right.$ depth) at $\mathrm{R}_{2}$ and $\mathrm{R}_{6}$ of maize crops also differed $(P<0.001)$ among landscape positions (Table 2$)$. The largest mean values were recorded at the foot-slope position ( 448 and $528 \mathrm{~mm}$ at $\mathrm{R}_{1}$ and $\mathrm{R}_{6}$, resp.), but soil water contents at the shoulder-slope position ( $\sim 60$ and $123 \mathrm{~mm}$ at $\mathrm{R}_{2}$ and $\mathrm{R}_{6}$, resp.) were similar than those recorded at the summit ( $\sim 86$ and $149 \mathrm{~mm}$ at $R_{1}$ and $R_{6}$, resp.). Differences among row spacings only were significant at $\mathrm{R}_{6}$ of maize crops at the foot-slope position $(P=0.06$, for landscape position $\mathrm{x}$ row spacing interaction), where maize cultivated with the skip-row pattern exhibited lower soil water content $(\sim 415 \mathrm{~mm})$ than those in narrow rows $(\sim 564$ and $606 \mathrm{~mm}$ for $0.38 \mathrm{~m}$ and $0.52 \mathrm{~m}$, resp.). Contrarily, at the summit maize crops cultivated with the skip-row pattern exhibited a higher soil water content $(\sim 223 \mathrm{~mm})$ than those in narrow rows $(\sim 113 \mathrm{~mm})$, but mentioned differences among row spacings were not significant due to the high intrafield variability of soil water contents at this landscape position (Figure 2). Differences in soil water contents at $\mathrm{R}_{1-2}$ and $\mathrm{R}_{6}$ between Ls were not significant.

Despite landscape position and row spacing effects on soil water content $(0-200 \mathrm{~cm}$ depth), a significant $(P<$ 0.001 ) linear regression described the relationship between soil water contents at $\mathrm{R}_{6}$ and at $\mathrm{R}_{1-2}$ for the whole data set as follows:

$$
\begin{aligned}
& \text { Soil water content at } \mathrm{R}_{6} \\
& =63+0.96 \text { soil water content at } \mathrm{R}_{1-2} \\
& \qquad\left(R^{2}=0.98, n=18\right) .
\end{aligned}
$$

At each $\mathrm{L}$, row spacing did not modify maximum fIPAR of maize crops (Tables 1 and 2). In $\mathrm{L}_{1}$, crops cultivated at both the foot- and the shoulder-slope positions exhibited greater $(P<0.01)$ maximum fIPAR $(\sim 0.93)$ than those grown at the summit $(\sim 0.81)$. In $\mathrm{L}_{2}$, the greatest maximum fIPAR $(P<$ $0.01)$ was recorded at the foot-slope position $(\sim 0.90)$, but the lowest values were recorded at the other landscape positions $(\sim 0.68-0.73)$.

Maize crops cultivated in $\mathrm{L}_{1}$ at the different landscape positions and row spacings exhibited similar SPAD readings ( $>52$; Table 1), which indicate SLNs $>1.55 \mathrm{~g} \mathrm{~N} / \mathrm{m}^{2}$ (based on $(2))$. In $\mathrm{L}_{2}$, the greatest SPAD reading ( 54 ; i.e., SLN $\left.>1.53 \mathrm{~g} \mathrm{~N} / \mathrm{m}^{2}\right)(P<0.05)$ was recorded at the foot-slope position and the lowest values $(\sim 44-45$; i.e., SLNs $\sim 1.18-$ $1.22 \mathrm{~g} \mathrm{~N} / \mathrm{m}^{2}$ ) were recorded at the other landscape positions (Table 2). Crops in rows $0.38 \mathrm{~m}$ apart exhibited lower SPAD readings $(\sim 46)$ than those with the other row spacings $(>48)$.
Differences in fIPARs and SPAD readings between Ls were not significant.

Differences among landscape positions and row spacings in maximum fIPAR values were related to soil water contents at $\mathrm{R}_{1-2}$ (Figure $\left.3(\mathrm{a})\right)$. A linear function significantly $\left(R^{2}=\right.$ $0.85, P<0.001)$ described the relationship between both variables. Similarly, a positive correlation $(r=0.79)$ was also found between SPAD readings and soil water contents at $R_{1-2}$, but the latter only accounted for $62 \%$ of SPAD readings variability.

At both Ls, landscape position affected $(0.001<P<0.01)$ total crop biomass, but only in $\mathrm{L}_{1}$ was this trait also affected $(P<0.01)$ by row spacing (Tables 1 and 2$)$. Mean values of crop biomass were maximized at the foot-slope positions ( $\sim 2247$ and $2105 \mathrm{~g} / \mathrm{m}^{2}$ in $\mathrm{L}_{1}$ and $\mathrm{L}_{2}$, resp.) and the lower values were found at the summits $\left(\sim 1662\right.$ and $1444 \mathrm{~g} / \mathrm{m}^{2}$ in $\mathrm{L}_{1}$ and $\mathrm{L}_{2}$, resp.). Crops at shoulder-slope position exhibited similar biomass than those cultivated at the foot-slope position in $\mathrm{L}_{1}$ $\left(\sim 2115\right.$ versus $\left.2247 \mathrm{~g} / \mathrm{m}^{2}\right)$ or at the summit in $\mathrm{L}_{2}(\sim 1445$ versus $\left.1444 \mathrm{~g} / \mathrm{m}^{2}\right)$. In $\mathrm{L}_{1}$ crops in rows $0.38 \mathrm{~m}$ apart yielded the lowest mean values of total biomass $(\sim 1880,2112$, and $2030 \mathrm{~g} / \mathrm{m}^{2}$ for $0.38 \mathrm{~m}, 0.52 \mathrm{~m}$, and the skip-row pattern, resp.). Total crop biomass was not affected by L.

Both grain yield and kernel number per unit land area varied along landscape positions $(0.01<P<0.05)$ in a similar way to total crop biomass (Tables 1 and 2) and differences among treatments on kernel number per unit land area were related to maximum fIPAR (Figure 3(b)). In $\mathrm{L}_{1}$, crops in rows $0.38 \mathrm{~m}$ apart exhibited the lowest grain yield, harvest index, and kernel number at any landscape position (i.e. landscape position $\mathrm{x}$ row spacing interaction was not significant) (Table 1). In $\mathrm{L}_{2}$ crops in rows $0.38 \mathrm{~m}$ apart also attained lower grain yields and kernel numbers per unit land area than those with the other row spacings, but differences in these traits among row spacings were not significant (Table 2).

Collectively, variations of kernel number per unit land area accounted for $89 \%$ of grain yield variability (Figure 3(c)), due to few changes of kernel weight and prolificacy (Tables 1 and 2). In $\mathrm{L}_{1}$, kernel weight $(P<0.10)$ and prolificacy $(P<0.01)$ decreased at the summit and foot-slope position, respectively. In $\mathrm{L}_{2}$, kernel weight decreased $(P<0.10)$ at the shoulder-slope position and crops in rows $0.38 \mathrm{~m}$ apart exhibited the lower $(P<0.05)$ prolificacy values. The latter trait was greater $(P<0.10)$ in $\mathrm{L}_{1}(\sim 1.6)$ than in $\mathrm{L}_{2}(\sim 1.1)$.

\section{Discussion}

Maize grain yield varied along the different landscape positions of the fields, as was previously reported in this subregion of the Pampas [6]. Landscape position effect on maize productivity seems to be related to the diverse soil water contents of the soils. The fitted relationship between soil water contents at $\mathrm{R}_{1}$ and at $\mathrm{R}_{6}$ suggests similar water availability for crops around silking and during the postsilking period. Hence, maize rainfed crops cultivated along the sandy landscape positions of these fields were growing with contrasting soil water contents during the most sensitive stages to water deficit [38, 39]. Similarly, in another sub-region of 
Summit
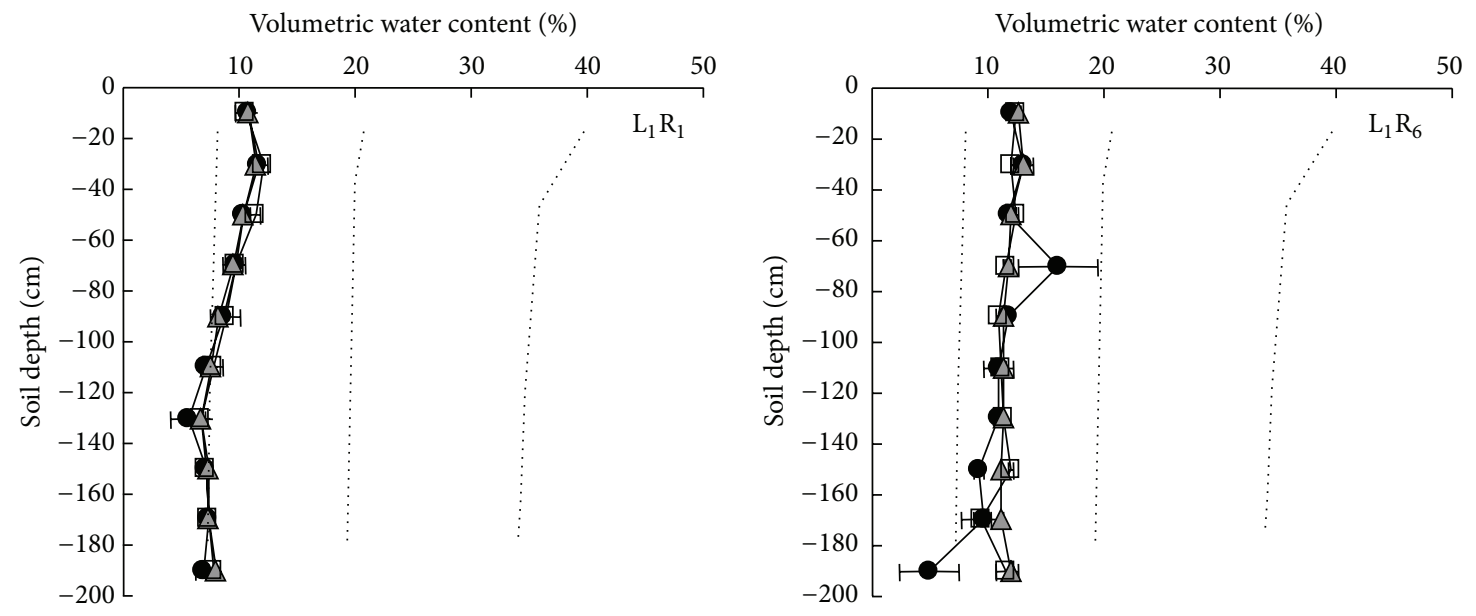

Shoulder-slope position

Volumetric water content (\%)

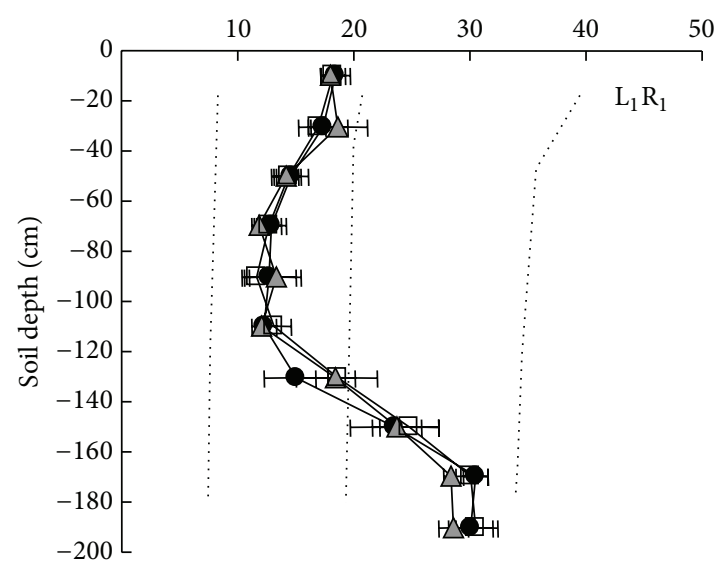

Volumetric water content (\%)

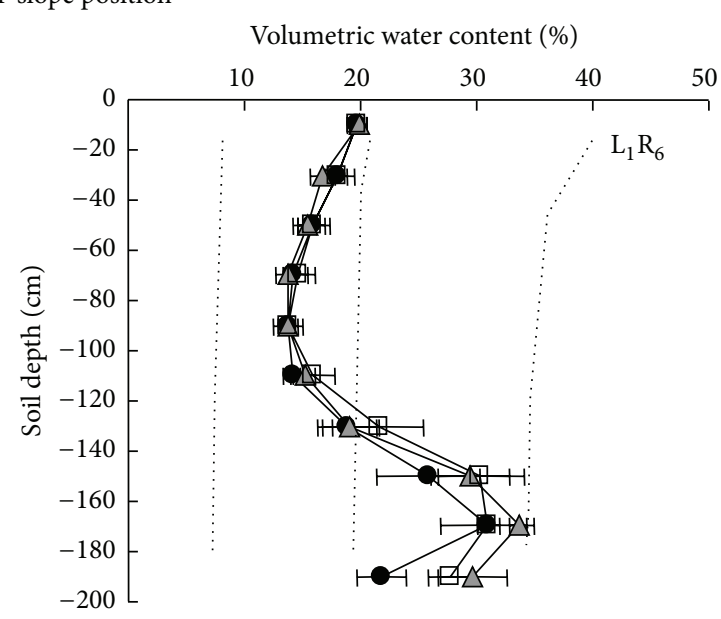

Foot-slope position

Volumetric water content (\%)
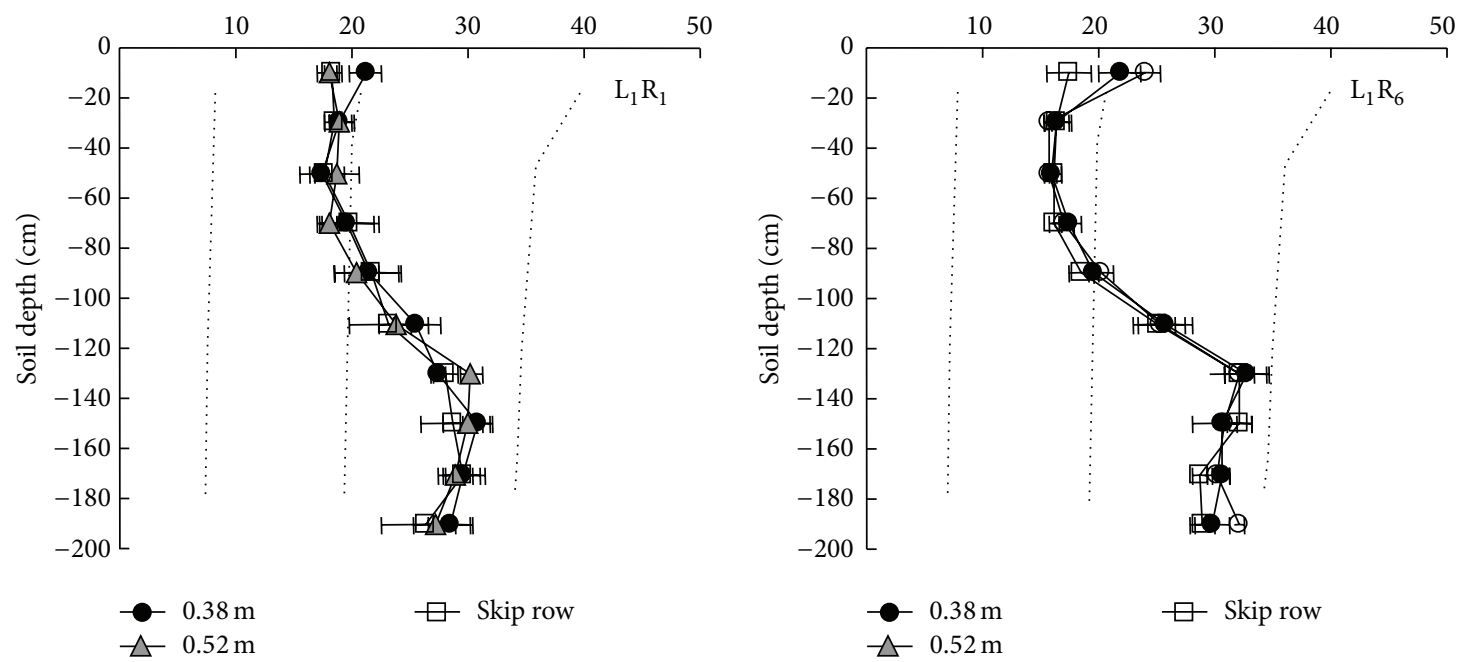

FIGURE 1: Volumetric water contents of soil profiles $\left(0-200 \mathrm{~cm}\right.$ depth) at silking $\left(\mathrm{R}_{1}\right)$ and physiological maturity $\left(\mathrm{R}_{6}\right)$ of maize crops cultivated at three landscape positions (summit, shoulder-slope position, and foot-slope position) and three row spacings $(0.38 \mathrm{~m}, 0.52 \mathrm{~m}$, and $0.38 \mathrm{~m}$ in a $2 \times 1$ skip-row pattern) during 2006/07 (location $1 ; \mathrm{L}_{1}$ ). Values are the mean \pm standard error of three replicates. Dotted lines indicate volumetric water contents at lower limit, upper limit, and saturation determined in laboratory. 


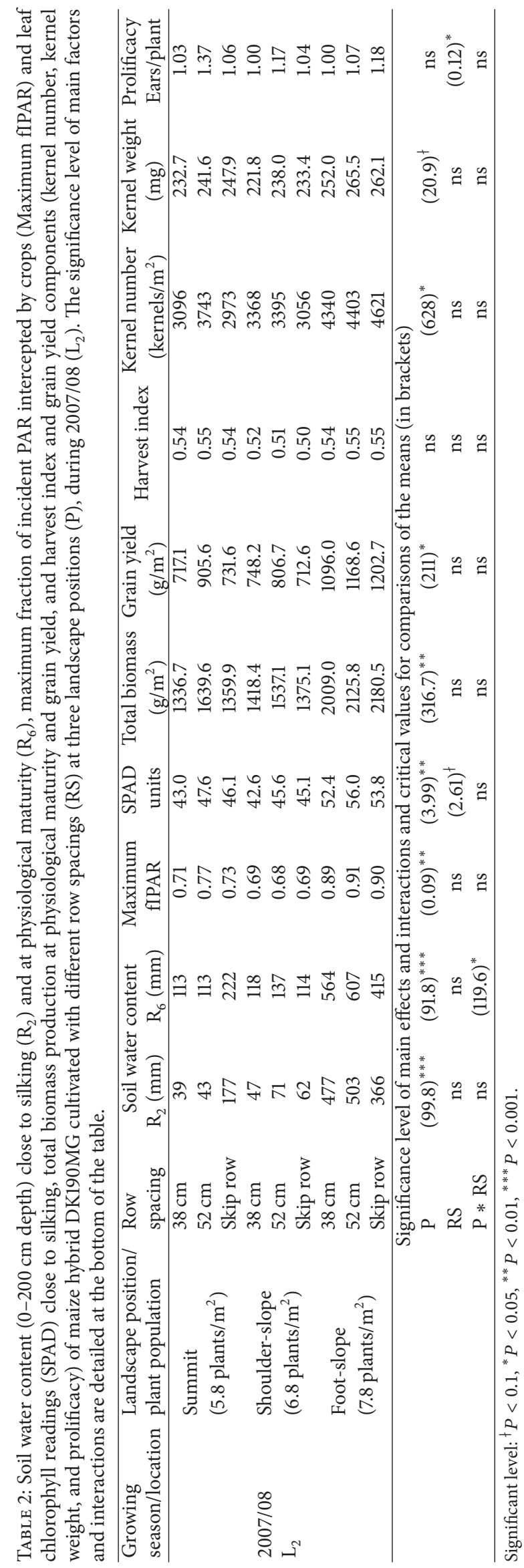


Summit
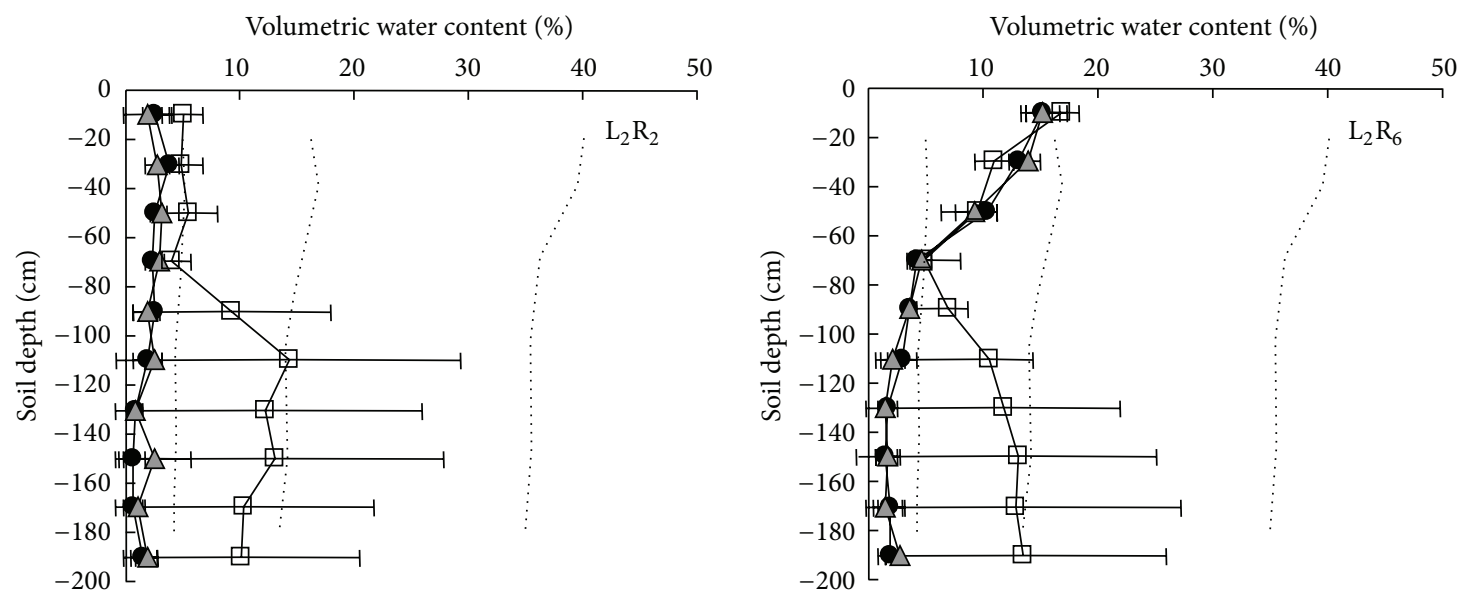

Shoulder-slope position
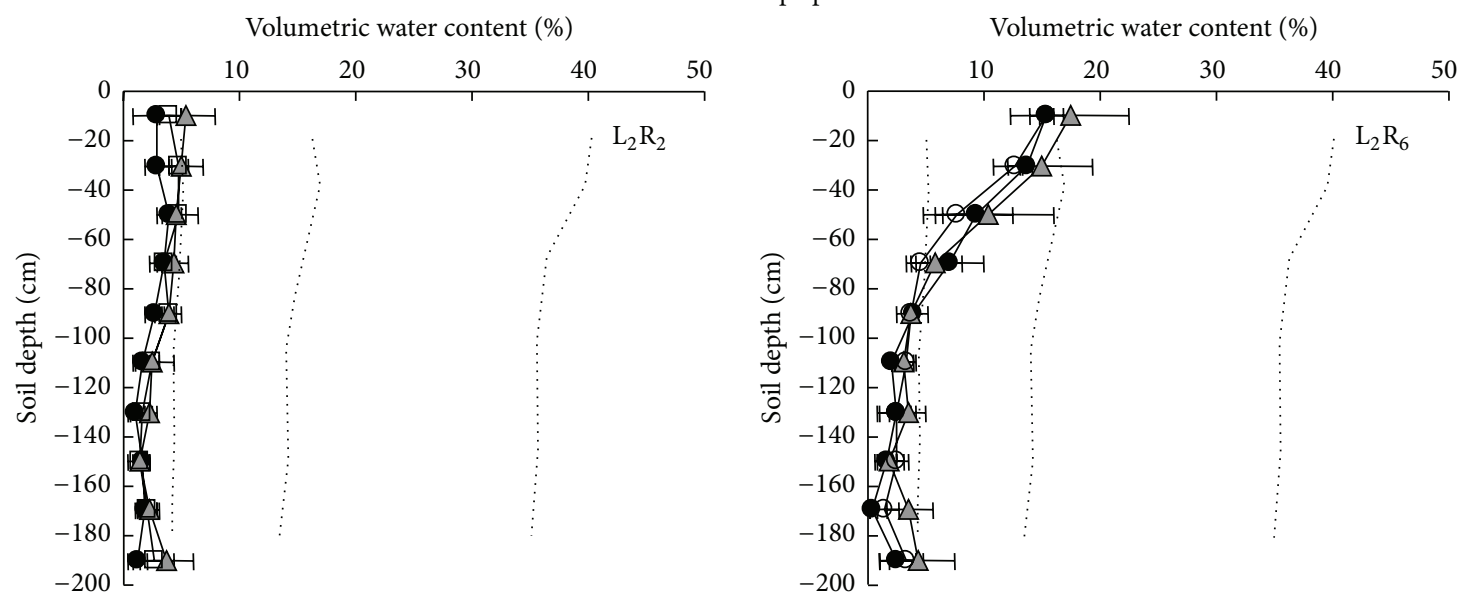

Foot-slope position

Volumetric water content (\%)
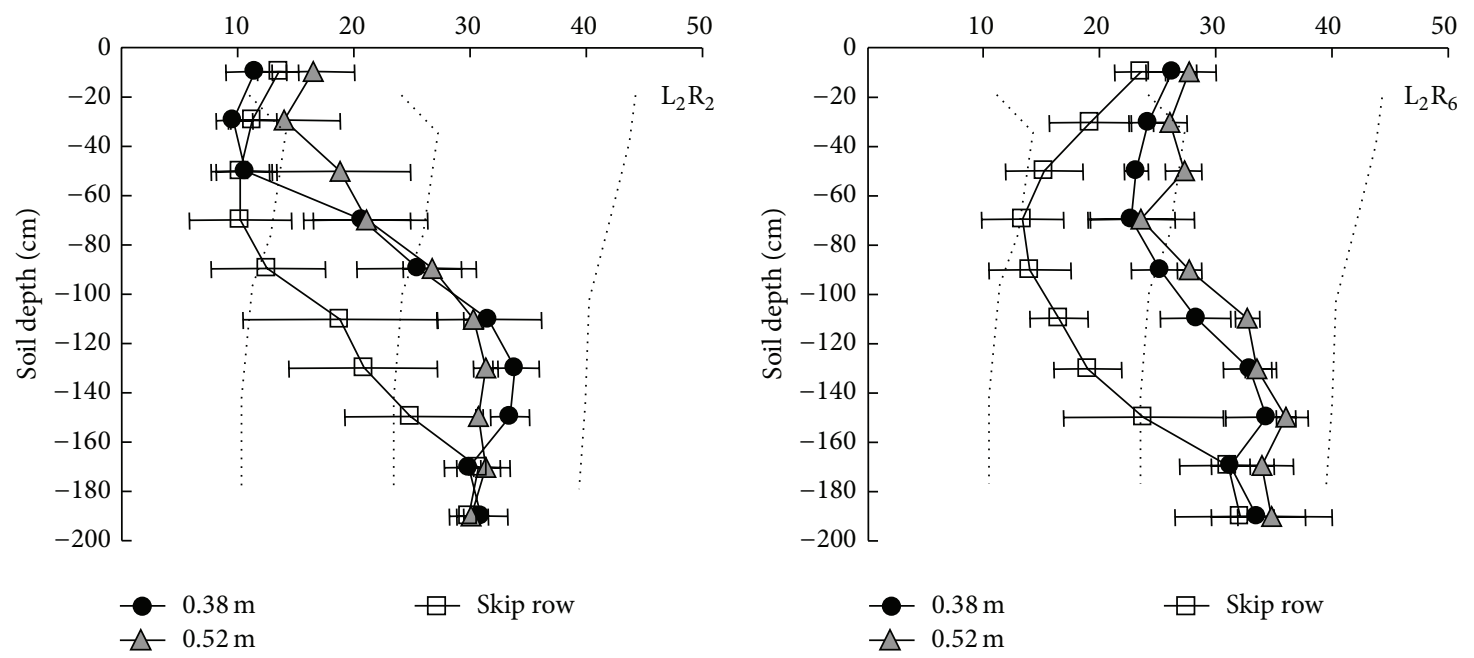

FIGURE 2: Volumetric water contents of soil profiles $\left(0-200 \mathrm{~cm}\right.$ depth) close to silking $\left(\mathrm{R}_{2}\right)$ and at physiological maturity ( $\left.\mathrm{R}_{6}\right)$ of maize crops cultivated at three landscape positions (summit, shoulder-slope position, and foot-slope position) and three row spacings $(0.38 \mathrm{~m}, 0.52 \mathrm{~m}$, and $0.38 \mathrm{~m}$ in a $2 \times 1$ skip-row pattern) during 2007/08 (location $2 ; \mathrm{L}_{2}$ ). Values are the mean \pm standard error of three replicates. Dotted lines indicate volumetric water contents at lower limit, upper limit, and saturation determined in laboratory. 


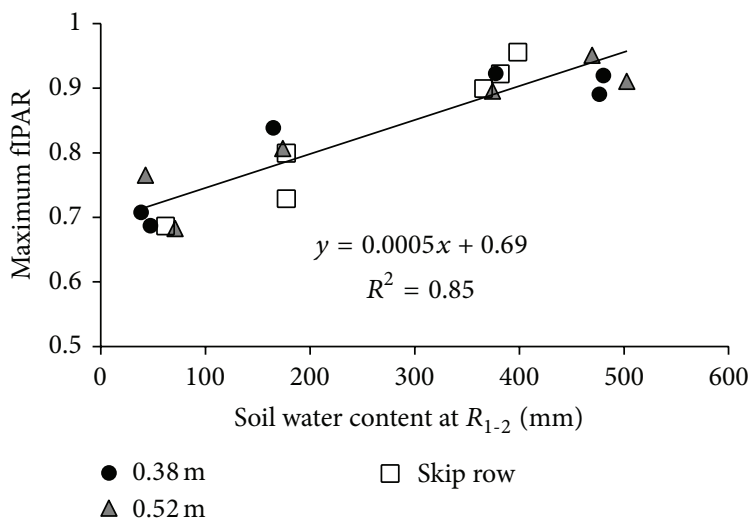

(a)

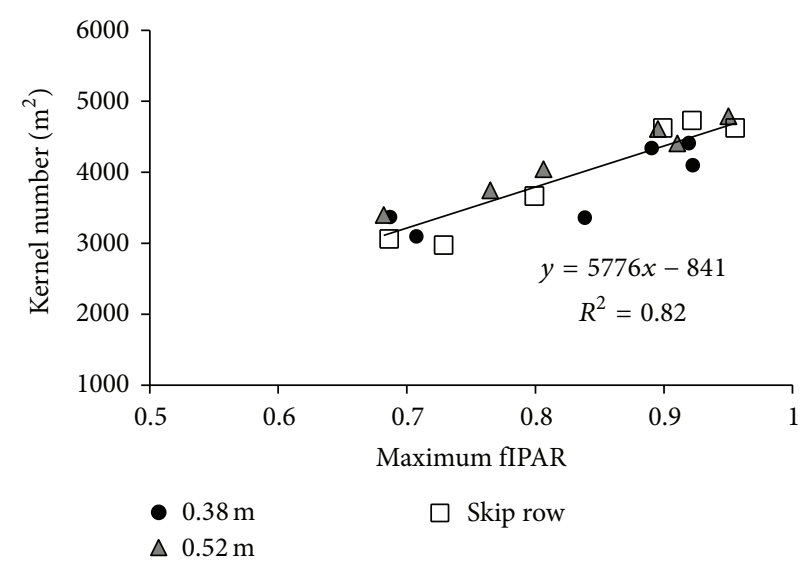

(b)

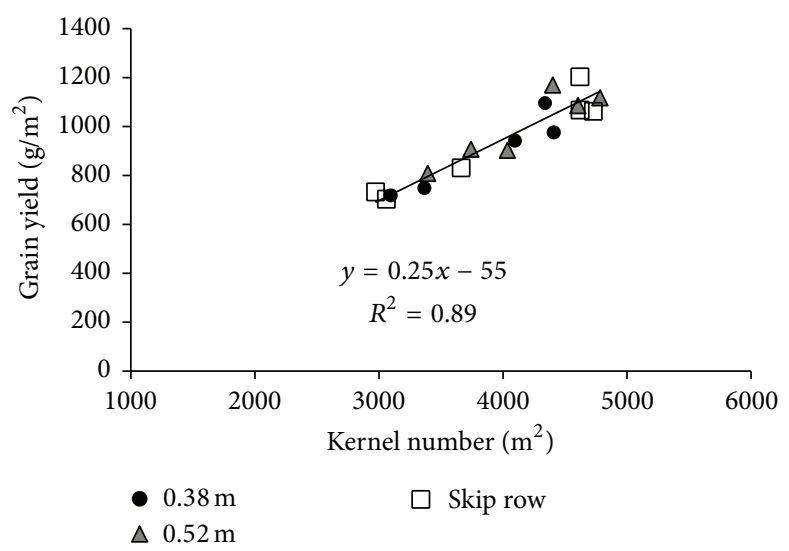

(c)

FIgURE 3: Maximum fraction of incident PAR intercepted (fIPAR) by crops as a function of soil water content $(0-200 \mathrm{~cm}$ depth) close to silking (a), kernel number as a function of maximum fIPAR (b), and grain yield as function of kernel number (c) of maize crops cultivated at three landscape positions with three row spacings $(0.38 \mathrm{~m}, 0.52 \mathrm{~m}$, and $0.38 \mathrm{~m}$ in a $2 \times 1$ skip-row pattern) during 2006/07 and $2007 / 08$. Values are the mean of three plots at each row spacing $\mathrm{x}$ landscape position. Lines indicate the models fitted to data sets.

the Pampas, the Southern Pampas, toposequence effect on maize grain yield was associated with the different water storage capacities of the soils: the highest capacity of the deep Typic Argiudolls at flat field areas and the lowest capacity of the shallow Petrocalcic Paleudolls at shoulder-slope positions [40]. In the Inland Pampas stored soil water capacity does not greatly differ among landscape positions, because both Hapludolls and Haplustolls do not exhibit any physical restriction (such as the petrocalcic layer of the Petrocalcic Paleudolls) to limit vertical root penetration of soil profile, and their lower limit of water extraction varies a little among landscape positions [41]. Hence, the existence of a shallow groundwater table close to soil layers colonized by roots [6] together with water runoff from uplands to lowlands [42, 43] could contribute to the different soil water contents of the analyzed landscape positions of these fields. Consequently, at the foot-slope positions these sources of water could mitigate [44] the effect of the negative water balance that frequently occurs at midsummer in this sub-region of the Pampas when the critical period of maize crops takes place [45].
The low soil water contents $\left(0-200 \mathrm{~cm}\right.$ soil depth) at $\mathrm{R}_{1-2}$ of crops cultivated at the summits of both Ls and at the shoulder-slope position of $\mathrm{L}_{2}$ (i.e. during the driest growing season) confirmed that the analyzed soil depth was fully colonized by roots during the presilking period $[39,46]$. It was speculated that crops in the skip-row pattern could exhibit higher water contents between rows than those in narrow rows, by a different spatial pattern of root distribution [28]. This trend was slightly detected at the summit of $\mathrm{L}_{2}$ during the driest growing season, but with a great plot to plot variability. Interestingly, at the foot-slope position of both Ls, crops in the skip-row pattern exhibited significantly lower soil water contents (at $\mathrm{R}_{1}$ in $\mathrm{L}_{1}$ and at $\mathrm{R}_{6}$ in $\mathrm{L}_{2}$ ) than those in narrow rows. These contrasting results could be related to the different plant population densities used at each landscape position. A detailed analysis of root spatial distribution from samples obtained within and between rows, coupled with periodical measurements of soil water content, would be necessary to establish row spacing $\mathrm{x}$ plant population density effect on root colonization and water consumption [28]. 
Contribution of groundwater to soil water availability for maize crops was confirmed at the foot-slope position of both Ls and at the shoulder-slope position in $\mathrm{L}_{1}$ (i.e. during the humid growing season). At $\mathrm{R}_{1-2}$ and $\mathrm{R}_{6}$, soil water contents of the deepest layers $(>140 \mathrm{~cm})$ were above the upper limit of water holding capacity ( 20-25\%) suggesting a capillary movement of water from the saturated zone ( 35-40\%) up to the root absorption zone. During the humid growing season $\left(\mathrm{L}_{1}\right)$, the greater soil water contents at $\mathrm{R}_{1}$ and $\mathrm{R}_{6}$ of crops within the $0-100 \mathrm{~cm}$ soil depth at the foot-slope position and within $0-20 \mathrm{~cm}$ at the shoulder-slope position were probably related to water runoff from uplands to lowlands [42, 43]. Hence, under these environments (landscape positions x Ls), maize crops were growing under contrasting water availabilities and differences in grain yield between foot-slope positions and the summits were higher (approximately $370 \mathrm{~g} / \mathrm{m}^{2}$ ) during the driest growing season (2007/08) than during the humid 2006/07 growing season (approximately $220 \mathrm{~g} / \mathrm{m}^{2}$ ). Similarly, differences in grain yield between foot-slope positions and shoulder-slope positions were $\sim 400 \mathrm{~g} / \mathrm{m}^{2}$ during $2007 / 08$ and less than $25 \mathrm{~g} / \mathrm{m}^{2}$ during 2006/07. Consequently, contribution of shallow groundwater and run-off to available soil water for maize growth was related to total amount of rainfalls during maize cycle [6].

Considering grain yield components, differences in grain yield per unit land area among treatments were mainly related to kernel number, which was closely related to maximum fIPAR. This well documented functional relationship, that is, kernel number per unit land area as a function of light capture $[9,21,22]$, summarizes the effects of environmental resources on canopy size and kernel set. Probably, leaf area of maize crops at the different landscape positions was regulated by soil water availability and other soil resources (e.g. N), especially during the presilking period [47]. In this study, temporal soil samplings during this period were not performed, but the significant relationship between soil water content at $R_{1-2}$ and maximum fIPAR suggests a positive effect of water availability on vegetative growth. This impact was particularly clear when comparing maximum fIPARs at each landscape position between Ls: at $\mathrm{L}_{2}$ crops were cultivated at higher plant population densities than at $\mathrm{L}_{1}$ but attained lower values of maximum fIPARs and soil water contents (Tables 1 and 2). Contribution of groundwater to maize growth during the presilking period needs to be tested, but in a previous work groundwater table depth did not considerably vary during the presilking period of maize crops [6].

Incident solar radiation around silking was similar between years (data not shown). Hence, the linearity of kernel number per unit land area and maximum fIPAR suggest a similar RUE among treatments, even at the most restrictive environments (i.e. the summits and the shoulder-slope position of $\mathrm{L}_{2}$ ) [48]. As was reported for sorghum crops [49], leaf extension is more sensitive than leaf transpiration (i.e., leaf conductance) to soil water reductions; hence RUE is sustained at soil water contents that affect leaf growth. A plant trait related to RUE is the SLN [33], which was estimated with SPAD readings [50]. Maize RUE declines with SLN < $1.2 \mathrm{~g} \mathrm{~N} / \mathrm{m}^{2}$ [33] and both water stress and $\mathrm{N}$ deficit affect SLN
[51]. For the tested hybrid, SPAD readings $<44$ would indicate SLNs $<1.2 \mathrm{~g} \mathrm{~N} / \mathrm{m}^{2}$, as was reported for other maize hybrids [32]. Only at the summit and the shoulder-slope position of $\mathrm{L}_{2}$, crops in rows $0.38 \mathrm{~m}$ apart exhibited SPAD readings below 44. Consequently, under these restrictive environments soil resources affected not only maximum fIPAR of crops in narrow rows but probably also their RUE.

Previous works reported a positive impact of the narrowest row spacing on fIPAR and grain yield under restrictive environments $[9,10]$ where farmers commonly use low plant population densities. In this work, crops cultivated at any landscape position with the narrowest row spacing (rows $0.38 \mathrm{~m}$ apart) attained similar maximum fIPARs to those cultivated in rows $0.52 \mathrm{~m}$ apart and also those with an uneven plant spatial distribution (i.e., the skip-row pattern). Re-orientation of maize leaves towards both intrarow and interrow spaces has been documented as an attribute of plant architecture that attenuates planting pattern effect on light capture [52]. A negative effect of the narrowest row spacing $(0.38 \mathrm{~m})$ on grain yield (6 to $20 \%$ of grain yield reduction), however, was recorded at all landscape positions of both Ls and was significant during the most humid growing season (in $\mathrm{L}_{1}$ ). Differences in grain yield between the narrowest row spacing and the other row spacings were not related to maximum fIPAR or to SPAD values with the exception of crops at the summit and at the shoulder-slope position of $\mathrm{L}_{2}$. Different light penetration within maize canopy strata [27] probably determined the lower kernel set of plants in narrow rows [26], which was reflected in their lower harvest index. Hence penalty of the narrowest row spacing on maize grain yield was related to not only the reduced biomass production but also the lower biomass partitioning to reproductive structures [21]. In order to estimate the effect of an incorrect choice of row spacing on grain yield at the field level, the area of each landscape position within the field would be known.

\section{Conclusions}

Maize grain yield varied along the different landscape positions of the fields, and this variation was higher in the second experiment with the driest growing season. Differences in grain yield among landscape positions were mainly determined by maximum fIPAR attained by crops at silking. A positive relationship between soil water content at silking and maximum fIPAR significantly described the different environments explored by maize crops. Row spacing did not modify fIPAR around silking or soil water availability. Grain yield reductions (6 to $20 \%$ ) were detected when crops were cultivated in the narrowest row spacing (rows $0.38 \mathrm{~m}$ apart) at the different landscape positions. The hypothesis that the use of the same row spacing for the different landscape positions of sandy fields could punish maize grain yield was tested. This hypothesis was partially rejected, because crops in rows $0.52 \mathrm{~m}$ apart attained optimum grain yields at each landscape position. Consequently, husbandry for maize rainfed crops cultivated in sandy fields with great water table depth variations could be based on site-specific management 
of plant population density, but with the same moderate row spacing (rows $0.52 \mathrm{~ms}$ apart).

\section{Conflict of Interests}

The authors declare that there is no conflict of interests regarding the publication of this paper.

\section{Acknowledgments}

This work was supported financially by LIAG Argentina S.A. and Dekalb-Monsanto Argentina S.A. The authors wish to thank G. Mangas, G. Sznaider, C. Mignone, M. Bustos, W. Tanaka, J. P. Burzaco, and E. Jobbágy for their valuable help. Gustavo Ángel Maddonni is a member of the National Council for Research (CONICET).

\section{References}

[1] A. Soriano, "Río de la Plata grasslands," in Ecosystems of the World. Natural Grasslands, R. T. Coupland, Ed., pp. 367-407, Elsevier Scientific, Amsterdam, Netherlands, 1991.

[2] Soil Survey Staff, Keys to Soil Taxonomy, USDA-Natural Resources Conservation Service, Washington, DC, USA, 11th edition, 2010.

[3] A. J. Hall, C. M. Rebella, and C. M. Ghersa, "Field-crop systems of the Pampas," in Ecosystems of the World. Field Crops Ecosystems, C. J. Pearson, Ed., pp. 413-450, Elsevier Scientific, Amsterdam, Netherlands, 1992.

[4] V. A. Barros, "Adaptation to climatic trends: lessons from the argentine experience," in Climate Change and Adaptation, N. Leary, I. Burton, J. Adejuwon, V. Barros, R. Lasco, and J. I. Kulkarni, Eds., pp. 296-350, Earthscan, London, UK, 2008.

[5] F. Damiano and M. A. Taboada, "Prediction of available soil water using pedo-transfer functions in agricultural soils of the pampeana region," Ciencia del Suelo, vol. 18, no. 2, pp. 77-88, 2000.

[6] M. D. Nosetto, E. G. Jobbágy, R. B. Jackson, and G. A. Sznaider, "Reciprocal influence of crops and shallow ground water in sandy landscapes of the Inland Pampas," Field Crops Research, vol. 113, no. 2, pp. 138-148, 2009.

[7] D. L. Karlen and C. R. Camp, "Row spacing, plant population and water management effects on maize in the Atlantic Coast Plain," Agronomy Journal, vol. 77, pp. 393-398, 1985.

[8] M. E. Westgate, F. Forcella, D. C. Reicosky, and J. Somsen, "Rapid canopy closure for maize production in the northern US corn belt: radiation-use efficiency and grain yield," Field Crops Research, vol. 49, no. 2-3, pp. 249-258, 1997.

[9] P. A. Barbieri, H. R. Sainz Rozas, F. H. Andrade, and H. E. Echeverria, "Row spacing effects at different levels of nitrogen availability in maize," Agronomy Journal, vol. 92, no. 2, pp. 283$288,2000$.

[10] P. Barbieri, L. Echarte, A. Della Maggiora, V. O. Sadras, H. Echeverria, and F. H. Andrade, "Maize evapotranspiration and water-use efficiency in response to row spacing," Agronomy Journal, vol. 104, no. 4, pp. 939-944, 2012.

[11] C. A. Norwood, "Dryland corn in western kansas: effects of hybrid maturity, planting date, and plant population," Agronomy Journal, vol. 93, no. 3, pp. 540-547, 2001.
[12] A. M. Hashemi, S. J. Herbert, and D. H. Putnam, "Yield response of corn to crowding stress," Agronomy Journal, vol. 97, no. 3, pp. 839-846, 2005.

[13] M. Popp, J. Edwards, P. Manning, and L. C. Purcell, "Plant population density and maturity effects on profitability of shortseason maize production in the Midsouthern USA," Agronomy Journal, vol. 98, no. 3, pp. 760-765, 2006.

[14] D. E. Farnham, "Row spacing, plant density, and hybrid effects on corn grain yield and moisture," Agronomy Journal, vol. 93, no. 5, pp. 1049-1053, 2001.

[15] G. A. Maddonni, M. E. Otegui, and A. G. Cirilo, "Plant population density, row spacing and hybrid effects on maize canopy architecture and light attenuation," Field Crops Research, vol. 71, no. 3, pp. 183-193, 2001.

[16] F. H. Andrade, P. Calviño, A. Cirilo, and P. Barbieri, "Yield responses to narrow rows depend on increased radiation interception," Agronomy Journal, vol. 94, no. 5, pp. 975-980, 2002.

[17] J. Bolaños and G. O. Edmeades, "Eight cycles of selection for drought tolerance in lowland tropical maize. I. Responses in grain yield, biomass, and radiation utilization," Field Crops Research, vol. 31, no. 3-4, pp. 233-252, 1993.

[18] M. E. Otegui, M. G. Nicolini, R. A. Ruiz, and P. A. Dodds, "Sowing date effects on grain yield components for different maize genotypes," Agronomy Journal, vol. 87, no. 1, pp. 29-33, 1995.

[19] M. Tollenaar, L. M. Dwyer, and D. W. Stewart, "Ear and kernel formation in maize hybrids representing three decades of grain yield improvements in Ontario," Crop Science, vol. 32, pp. 432438, 1992.

[20] K. J. Boote and R. S. Loomis, "The prediction of canopy assimilation," in Modeling Crop Photosynthesis from Biochemistry to Canopy, K. J. Boote and R. S. Loomis, Eds., Special publication 19, pp. 109-140, Crop Science Society, Madison, Wis, USA, 1991.

[21] G. A. Maddonni, A. G. Cirilo, and M. E. Otegui, "Row width and maize grain yield," Agronomy Journal, vol. 98, no. 6, pp. 15321543, 2006.

[22] F. H. Andrade, S. A. Uhart, and M. I. Frugone, "Intercepted radiation at flowering and kernel number in maize: shade versus plant density effects," Crop Science, vol. 33, no. 3, pp. 482-485, 1993.

[23] A. N. Kravchenko and D. G. Bullock, "Correlation of corn and soybean grain yield with topography and soil properties," Agronomy Journal, vol. 92, no. 1, pp. 75-83, 2000.

[24] J. P. Schmidt, N. Hong, A. Dellinger, D. B. Beegle, and H. Lin, "Hillslope variability in corn response to nitrogen linked to inseason soil moisture redistribution," Agronomy Journal, vol. 99, no. 1, pp. 229-237, 2007.

[25] M. P. Bange, P. S. Carberry, J. Marshall, and S. P. Milroy, "Row configuration as a tool for managing rain-fed cotton systems: review and simulation analysis," Australian Journal of Experimental Agriculture, vol. 45, no. 1, pp. 65-77, 2005.

[26] C. O. Gwathmey, L. E. Steckel, and J. A. Larson, "Solid and skip-row spacings for irrigated and nonirrigated upland cotton," Agronomy Journal, vol. 100, no. 3, pp. 672-680, 2008.

[27] T. Liu, F. Song, S. Liu, and X. Zhu, "Canopy structure, light interception, and photosynthetic characteristics under different narrow-wide planting patterns in maize at silking stage," Spanish Journal of Agricultural Research, vol. 9, no. 4, pp. 1249-1261, 2011.

[28] B. S. Sharratt and D. A. McWilliams, "Microclimatic and rooting characteristics of narrow-row versus conventional-row corn," Agronomy Journal, vol. 97, no. 4, pp. 1129-1135, 2005. 
[29] J. L. Ping, R. B. Ferguson, and A. Dobermann, "Site-specific nitrogen and plant density management in irrigated maize," Agronomy Journal, vol. 100, no. 4, pp. 1193-1204, 2008.

[30] S. W. Ritchie, J. J. Hanway, and G. O. Benson, "How a corn plant develops," Special Report 48, Iowa State University, Ames, Iowa, USA, 1993.

[31] F. Flénet, J. R. Kiniry, J. E. Board, M. E. Westgate, and D. C. Reicosky, "Row spacing effects on light extinction coefficients of corn, sorghum, soybean, and sunflower," Agronomy Journal, vol. 88, no. 2, pp. 185-190, 1996.

[32] T. M. Blackmer, J. S. Schepers, and G. E. Varvel, "Light reflectance compared with other nitrogen stress measurements in corn leaves," Agronomy Journal, vol. 86, no. 6, pp. 934-938, 1994.

[33] T. R. Sinclair and T. Horrie, "Leaf nitrogen, photosynthesis and crop radiation use efficiency: a review," Crop Science, vol. 29, no. 1, pp. 90-98, 1989.

[34] I. Rajcan, L. M. Dwyer, and M. Tollenaar, "Note on relationship between leaf soluble carbohydrate and chlorophyll concentrations in maize during leaf senescence," Field Crops Research, vol. 63, no. 1, pp. 13-17, 1999.

[35] E. C. Montgomery, "Correlations studies in corn," in Nebraska Agricultural Experimentation Station Annual Report 24th, pp. 108-159, Nebraska Agricultural Experimentation Station, Lincoln, Ore, USA, 1911.

[36] W. Horwitz, A. Senzel, and H. Reynolds, Official Methods of Analysis, Association of Officinal Analytical Chemists, Washington, DC, USA, 12th ed edition, 1975.

[37] J. Tblcurve, TableCurve 3.0 Curve Fitting Software, Jandel Scientific, Corte Madera, Calif, USA, 1992.

[38] A. J. Hall, H. D. Ginzo, J. H. Lemcoff, and A. Soriano, "Influence of drought during pollen-shedding on flowering, growth, and yield of maize," Journal of Agronomy and Crop Science, vol. 149, no. 4, pp. 287-298, 1980.

[39] M. E. Otegui, F. H. Andrade, and E. E. Suero, "Growth, water use, and kernel abortion of maize subjected to drought at silking," Field Crops Research, vol. 40, no. 2, pp. 87-94, 1995.

[40] P. A. Calviño, F. H. Andrade, and V. O. Sadras, "Maize yield as affected by water availability, soil depth, and crop management," Agronomy Journal, vol. 95, no. 2, pp. 275-281, 2003.

[41] J. L. Dardanelli, O. A. Bachmeier, R. Sereno, and R. Gil, "Rooting depth and soil water extraction patterns of different crops in a silty loam haplustoll," Field Crops Research, vol. 54, no. 1, pp. 2938, 1997.

[42] A. Y. Hanna, P. W. Harlan, and D. T. Lewis, "Soil available water as influenced by landscape position and aspect," Agronomy Journal, vol. 74, no. 6, pp. 999-1004, 1982.

[43] A. Y. Hanna, P. W. Harlan, and D. T. Lewis, "Effect of landscape position and aspect on soil water recharge," Agronomy Journal, vol. 75, no. 1, pp. 57-60, 1983.

[44] J. E. Ayars, E. W. Christen, R. W. Soppe, and W. S. Meyer, "The resource potential of in-situ shallow ground water use in irrigated agriculture: a review," Irrigation Science, vol. 24, no. 3, pp. 147-160, 2006.

[45] M. Díaz-Zorita, G. A. Duarte, and J. H. Grove, "A review of notill systems and soil management for sustainable crop production in the subhumid and semiarid Pampas of Argentina," Soil and Tillage Research, vol. 65, no. 1, pp. 1-18, 2002.

[46] J. Carcova, G. A. Maddonni, and C. M. Ghersa, "Long-term cropping effects on maize: crop evapotranspiration and grain yield," Agronomy Journal, vol. 92, no. 6, pp. 1256-1265, 2000.
[47] D. S. NeSmith and J. T. Ritchie, "Short- and long-term responses of corn to a pre-anthesis soil water deficit," Agronomy Journal, vol. 84, no. 1, pp. 107-113, 1992.

[48] R. C. Muchow, "Comparative productivity of maize, sorghum and pearl millet in a semi-arid tropical environment II. Effect of water deficits," Field Crops Research, vol. 20, no. 3, pp. 207219, 1989.

[49] W. D. Rosenthal, G. F. Arkin, P. J. Shouse, and W. R. Jordan, "Water deficit effects on transpiration and leaf growth," Agronomy Journal, vol. 79, no. 6, pp. 1019-1026, 1987.

[50] S. C. Chapman and H. J. Barreto, "Using a chlorophyll meter to estimate specific leaf nitrogen of tropical maize during vegetative growth," Agronomy Journal, vol. 89, no. 4, pp. 557-562, 1997.

[51] D. W. Wolfe, D. W. Henderson, T. C. Hsiao, and A. Alviño, "Interactive water and nitrogen effects on senescence of maize. II. Photosynthetic decline and longevity of individual leaves," Agronomy Journal, vol. 80, no. 6, pp. 865-870, 1988.

[52] G. A. Maddonni, M. Chelle, J.-L. Drouet, and B. Andrieu, "Light interception of contrasting azimuth canopies under square and rectangular plant spatial distributions: simulations and crop measurements," Field Crops Research, vol. 70, no. 1, pp. 1-13, 2001. 


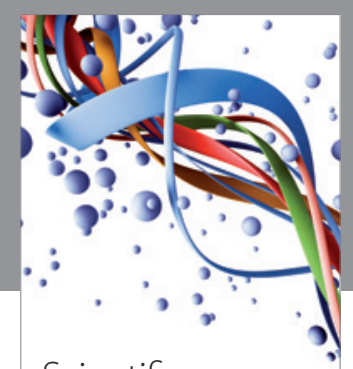

Scientifica
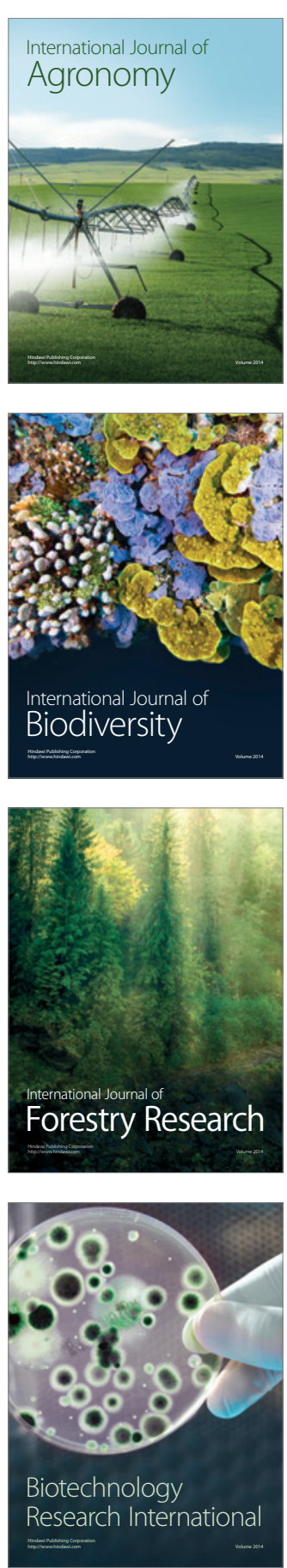
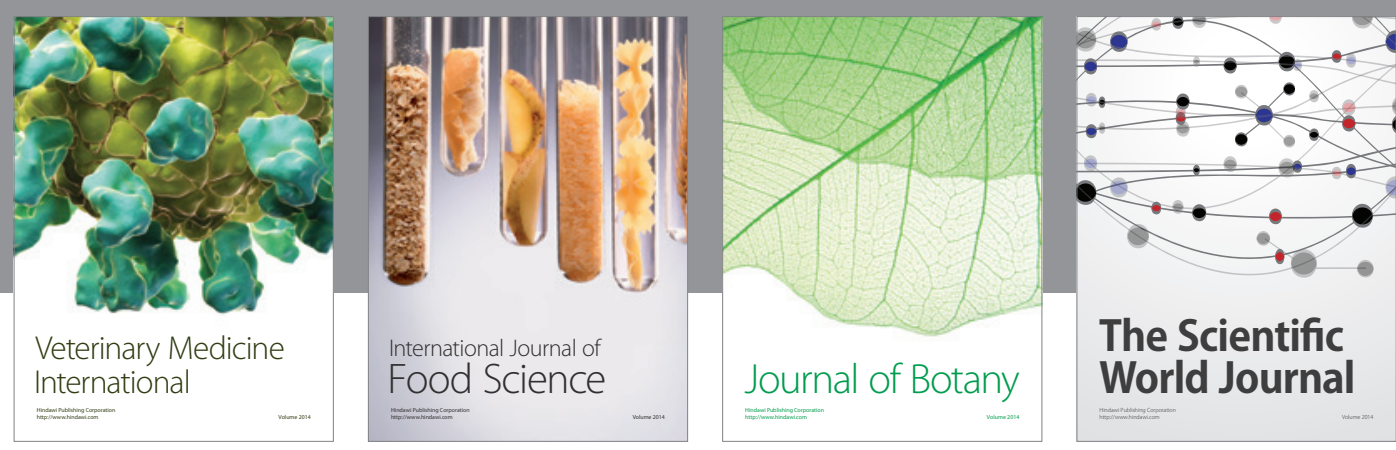

The Scientific World Journal
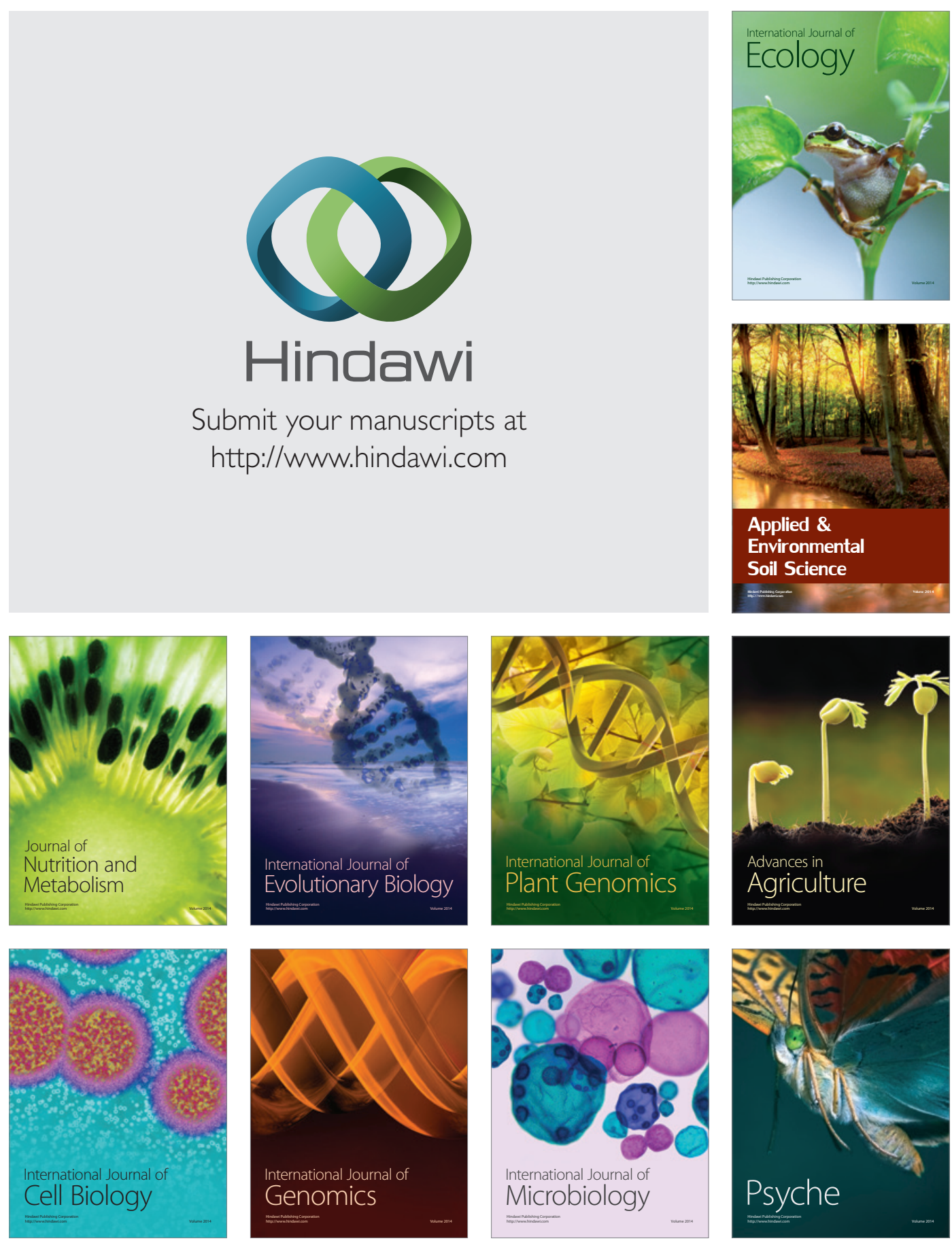